\title{
World Congress of Comparative Education, Istanbul, June, 2010
}

The last World Congress of Comparative Education, historically already the fourteenth one, has been in many respects extraordinary. It was held during celebrating the $40^{\text {th }}$ anniversary of World Council of Comparative Education Societies (established in 1970) and it was as well the largest congress so far (there were 1500 participants from 111 countries coming from all continents, among them a great deal of doctoral students and young researchers in the fields of comparative education).

The international congress called Bordering, Re-bordering and New Possibilities in Education and Society took place in Istanbul, Turkey, which is a large multicultural city inhabited with more than 20 million people and situated in pretty unique geographical location between two continents which are interconnect by two bridges over the Bosporus. Its atmosphere of modern, dynamic and vibrant city with antic Greek, Christian and Islamic historical roots made extremely supportive grounds for the main conference topic too.

The host institution, Bogazici University, is one of the most distinguished universities in the whole Turkey with extended international networks and cooperation. The organizers provided everything necessary for the conference, pretty nice was a high number of visible (orange T-shirts) volunteers recruited from the university students in the fields of educational science.

The main focus of the congress was put into analyzing the processes going on in the globalized world of today and the huge social transformations which are relevant for the education. The key concept "border" opened a discussion form the very beginning not only about movement in terms of geopolitics but as well in terms of changes, problems and limits in education which are interrelated with social processes and new challenges for the future development of schooling for the $21^{\text {st }}$ century. Topics like time and space relativity, overcoming of social, cultural and psychological boundaries as well as activating new ones which do influent personal and social identities on the local as well as global level were in the center of the discussions too. Problems of inclusion and exclusion in society in general and in education in particular as well as educational policy and its effects and influence in the fields of education in global context brings new opportunities and challenges which was the main "red line" going through the whole conference. Discrepancies between neo-liberal rhetoric combined with economic interests and political support on the one hand and widening inequalities in real education opportunities and access to high quality education for different social, cultural, ethnic and other social groups, were identified as a main problem calling for new solutions. Comparative education and international scientific community should contribute to its solution, in terms of theoretical analyses, empirical research projects as well as applied development programs focusing on real changes in the fields. 
Conference program was divided into keynote lectures and into following 13 parallel thematic sessions:

Educational Governance, Policy Within and Across Borders

Comparative education: Rethinking Theory and Method

Education, Conflict and Transitions Within and Between Societies

Demystifying Quality in Education

Re-imagining Curriculum

Critical Perspective in Teachers Education and Development

Identity, Space and Diversity in Education

Education, Human and Social Development and Capabilities

New Technologies and Accessibility to Learning

Education and Children's Rights in a "Globalized" World

Education, Politics of Dominance, the Suppressed and Disappearing Languages

Privatization and Marketization in Education

Education, Migration, Citizenship and the State

Cross-Thematic Groups: Special Interest Groups, Workshops, Symposia and Round tables

Each thematic session was further divided into several dozen sub-sections which were going on in forty rooms in six modern buildings in two separated parts of the university campus. From this single fact, it is possible to see how extensive the conference program was (the conference program had 168 pages and the book of abstracts even 570 pages).

All keynote lectures were extraordinary and highly critical toward contemporary trends in educational policy on all levels, from global and transnational to national and local level, which influence education and deform its democratic mission.

Michael W. Apple, one of the greatest world comparativists from universities in Wisconsin and London who cooperate with a great number of educational institutions and international organizations, raised his thesis in a lecture named Understanding and Interrupting Neoliberal and Neoconservative Policies in Education. $\mathrm{He}$ focused on critical analyses of contemporary trends in educational policy which empower growing selectivity, uneven distribution of financial resources and is influenced by those of the interest groups that are powerful thanks to populism and erosion of public education sector. Michael Apple expects the solution from the grass root mobilization of civic society and teacher organizations, from the good job done by teachers and curriculum accommodation toward the needs of the community. He was highly critical toward standardization of educational outputs, measuring of performance and testing of pupils on all levels of education which leads to high competition among schools and suppressing different educational needs among marginal groups in risk. He as well noticed positive growing role of social movements at universities as an increasingly important education policy actor which should not be underestimated and should be an issue of research too. Other examples of relevant social movements are various immigrant groups which sometimes create its own "educational systems" as a mean of defense against 
authoritarianism and management and market approach of more successful members of mainstram middle class (for example Afro-American schools in the United States, so called civic schools in Brazil). At the same time the speaker warned against exclusion, home education and those social movements that organize independent education which is growing especially in China and India. Michael Apple called for more elaborated research of positive examples of those teachers and schools which were able to make a change, promoted pupils integration toward public educational sector and made possible successful prolongation of their future studies at secondary and even tertiary education levels and stimulated their participation on wider society. The keynote lecture was in fact rooted in the last speaker book Global Crises, Social Justice and Education (2010) which is a piece of reference for those who are interested in learning more about the topics and issues raised in the keynote speech.

Suzan Robertson is a sociologist form Bristol University; she funded a Center for global, educational and social studies. Her keynote topic was The New Spatial Politics of Rebordering and (Re) bordering the State -Education -Citizen Relation for the Global Economy and she analyzed structural transformation which creates new borders for nation states, nations, citizens and educational domain. She drew on the writings of Basil Bernstain and called for a re-conceptualization of neo-liberal policy projects which are from their perspective unsustainable. She identified four broader trends (de -nationalization, de-etatization, de-sectorialization and de-politization) in the sphere of education which should strengthen contemporary discourses about lifelong learning and knowledge society in public sector which should liberate human potential and support personal as well as social development.

Rather different in form, background and goals was a keynote addressed by Zubeyda Kilic who is a leader of one among several Turkish teachers unions. Her speech tended to be activist but at the same time very authentic from the European point of view. She focused first of all on the political context of teacher profession and union in Turkey which were illegal for most of the $20^{\text {th }}$ century Turkish history. It went through difficult times during several military coups and heavy repressions by police special forces and military including torturing and imprisonment of leaders and protesters. She gave unionist point of view on contemporary issues and problems like marketization, privatization, cutting educational budget, teacher salaries, growing role of Islam in education, gender and language discrimination (for example Kurdish or Zaza language and schools were not legal for many decades of Turkish republic), selectivity and inequality in education which leads to greater class differences (one of the biggest and most controversial single problem in Turkish education is centralized state school-leaving exam which alters into a national drama each year).

During parallel sessions, panels, symposia and round tables discussions took their part renowned world scholars in the fields of comparative education, namely A. Welch, L. Tickly, M. Bray, M. Tatoo, A. Wiseman, J. Schriever, Gita Steiner-Khamsi among others. Strong attendance was visible from countries like the United States, Great Britain, Scandinavia and Western Europe, China, Japan, south-east Asia, 
South Africa and other African countries. There were as well participants from Latin America. Great attention was paid to participant from countries like Afghanistan, Nepal, and Kazakhstan which do have in common the fact that the comparative education in pretty new field of research there. Unfortunately, the presents of speakers and participants from Central Europe and other post-communist countries was rather weak, only two participants came from the Czech Republic (both from the Institute for Research and Development of Education, Charles University, Prague).

Among them Eliška Walterová presented a paper Crossing Borders into the Common European Educational Space. It was based on international comparative research project among so called Visegrad countries within the frame of the Centre for Basic Research on Schooling. It is developing theoretical framework for analyzing educational change and covers a blind spot in contemporary comparative education. It promoted a discussion about specific ways of educational change and transformation after political regime change as well as about more general and often global contemporary trends in education, growing similarities and persistent differences in schooling among different countries.

Karel Černý made a "hot issue" presentation called Feeling of Justice Inside and Outside School in Comparative Education: Mainstream and Muslim Immigrant Background Pupils in France, Italy, Belgium and England. It was based on extensive international empirical survey funded by European Commission focusing on perception of justice among 14-years old pupils in four European countries (random sample with more than 12 thousands pupils). It compared feeling of justice inside as well as outside school among Muslim and mainstream society background pupils. The results were pretty surprising because the main hypothesis assuming significantly higher rates of frustrations related to feeling of injustice among young European Muslims wasn't confirmed at all (the only exception was the French case, but the differences were not that huge anyway). The research is an important evidence based contribution to contemporary debate about possibilities and limitation of European multiculturalism.

Book and journal presentation and display were part of the congress program too. English issues of the Czech journal Orbis scholae were promoted on behalf on it too. Pretty inspiring and fruitful was a panel of comparative education journal editors. Refreshing events were parallel documentary movies presentations focusing on educational problems in Turkey and other countries too.

Special occasion was a panel dedicated to the $40^{\text {th }}$ WCCES anniversary. It focused on the most important milestones in the history of WCCES. Ex-presidents Mark Bray, Anne Hickling Hudson, Vandra Masemann nad Ervin Epstein gave their speech too and Eliška Walterová reminded everybody about the $8^{\text {th }}$ congress held in Prague in 1992. The WCCES has got 38 members who are part of 29 national and sub-national societies, 7 regional associations (European, American, Asian, Mediterranean, Scandinavian, Australian and Arab Gulf as a new one) which fully covers all the world continents.

Karel Černý and Eliška Walterová 